\title{
Development and testing of an alternative dissipative post-tensioned rocking timber wall with boundary columns
}

\author{
Francesco Sarti ${ }^{1}$, Alessandro Palermo ${ }^{2}$, Stefano Pampanin ${ }^{3}$
}

\section{Abstract}

The unbonded post-tensioned rocking and dissipative technology was first developed as the main outcome of the PRESSS (PREcast Seismic Structural Systems) Program in US.

After the first developments and significant refinement, the technology was extended to steel and, more recently, timber structures. The timber version, referred to as Pres-Lam (Prestressed laminated) system can be either implemented for timber walls (single or coupled) or frames or combination of the above, with unbonded post-tensioning and supplemental dissipation devices.

In unbonded post-tensioned dissipative wall systems a combination of re-centering capacity and energy dissipation leads to a "controlled rocking" mechanism which develops a gap opening at the wall base. This generates an uplift displacement which is transferred to the floor diaphragm. This vertical displacement incompatibility can represent a potential issue if the connection detailing between floor and lateral resisting system is not designed properly.

The same issue can be mitigated by adopting an alternative configuration of the rocking/dissipative wall system, based on the use of a column-wall-column post-tensioned connection. This concept, originally proposed for precast concrete walls and referred to as PreWEC (Prestressed Wall with End Column), has been extended and adapted to posttensioned timber structures and validated through experimental testing.

The paper presents the design, detailing and experimental testing of a two-thirds scale wall specimen of this alternative configuration. Different wall configurations are considered in terms of post-tensioning initial force as well as dissipation devices layout. The experimental

\footnotetext{
${ }^{1}$ Timber Research Engineer, Department of Civil and Natural Resources Engineering, University of Canterbury, Private Bag 8400, 8140, Christchurch, New Zealand

2 Associate Professor, Department of Civil and Natural Resources Engineering, University of Canterbury, Private Bag 8400, 8140, Christchurch, New Zealand

${ }^{3}$ Professor, Department of Civil and Natural Resources Engineering, University of Canterbury, Private Bag 8400, 8140, Christchurch, New Zealand
} 
results confirm the excellent seismic performance of the system with the possibility to adopt multiple alternative configurations.

\section{Introduction}

Multi-storey timber buildings has been and is being widely used for the construction of residential buildings where short spans are required and several walls can be positioned within the building without interfering with the architectural layout. This was mainly done by using light timber framing systems with sheathing of plywood or other materials. While providing significant ductility, those systems generally highlight significant stiffness and strength degradation (Gupta et al., 1987; Stewart, 1987; Deam, 1996; Karacabeyli et al., 1999; Durham et al., 2001; Filiatrault et al., 2009; Källsner et al., 2009; van de Lindt et al., 2010; Kirkham et al., 2013).

In the last decade engineered wood products such as Cross-Laminated Timber (CLT) has been widely used in the construction of residential and commercial buildings worldwide.

CLT lateral resisting walls rely on the hold-down connections to provide ductility to the building and this is capable to generate significant dissipation, yet displaying stiffness and strength degradation typical of nailed connections (Ceccotti et al., 2006a; Ceccotti et al., 2006b; Ceccotti, 2008; Dujic et al., 2010; Ceccotti et al., 2013; Gavric et al., 2015; Germano et al., 2015).

As an alternative low-damage solution, post-tensioned rocking dissipative connections are a structurally efficient and robust technology for seismic-resistant multi-storey buildings.

The technology was first proposed and developed during the PREcast Seismic Structural Systems (PRESSS) program, coordinated by the University of California San Diego (Priestley, 1991). The hybrid connection (Stanton et al., 1991) proved to be a very stable and promising solution among others tested in the final experimental stage of the PRESSS program. The connection provides a combination of re-centering and dissipative contributions which are given by post-tensioned high-strength steel reinforcement and mild steel dissipaters. In general, the behaviour of the dissipative post-tensioned rocking mechanism can be obtained by combination of a non-linear elastic and an elastic-plastic (with hardening) hysteresis, resulting into a peculiar self-centering and dissipative flag-shape hysteresis loop as shown in Figure $1 b$. 

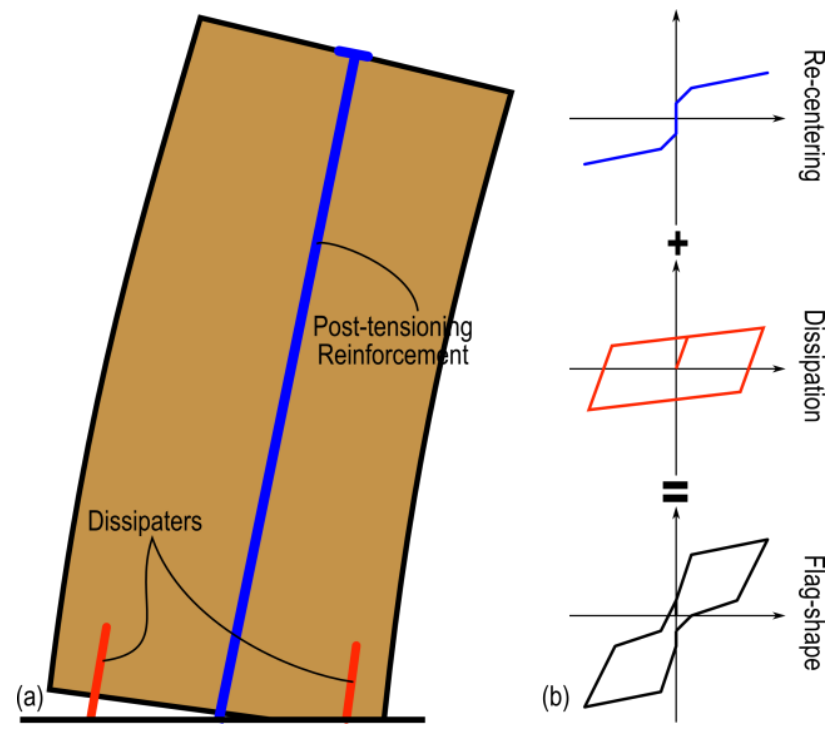

Figure 1.(a) Typical mechanism of a post-tensioned timber (Pres-Lam) rocking-dissipative system and (b) flagshape hysteresis.

After the first development of PRESSS-technology for both frames and wall systems (Priestley et al., 1999), further research and development has been carried out on the wall solution (Kurama et al., 1999; Kurama, 2000; Kurama, 2002; Holden et al., 2003; Morgen et al., 2007; Marriott et al., 2008).

The concept of hybrid connection (i.e., rocking dissipative) has been recently proved to be material independent, and extended to different materials as steel (Christopoulos et al., 2002), and timber (Palermo et al., 2005a) The timber version, referred to as Pres-Lam (Prestressed Laminated) system, consists of post-tensioned structural frames or walls, or combination of the two, based on alternative engineered wood solutions as Laminated Veneer Lumber (LVL) (Palermo et al., 2005a; Palermo et al., 2006; Smith et al., 2007; Iqbal et al., 2012), Glue Laminated timber (Glulam) (Smith et al., 2013) or Cross-Laminated timber (CLT or X-Lam) (Dunbar et al., 2014).

A possible issue with the rocking mechanism is related to vertical displacement incompatibilities between the lateral resisting system and the diaphragm connection. In fact, the uplifting generated at the wall base by the connection rotation is transferred to the drag beams or other similar collector system, if any, (see Figure 2) and can lead to potential damage to the diaphragm (Henry et al., 2012b). It is worth noting that an analogous issue occurs in monolithic concrete shear walls, where the plastic hinge development and further elongation due to lack of inherent re-centering mechanism result into wall uplifting (Fenwick et al., 1993; fib, 2003) and consequential diaphragm damage. 

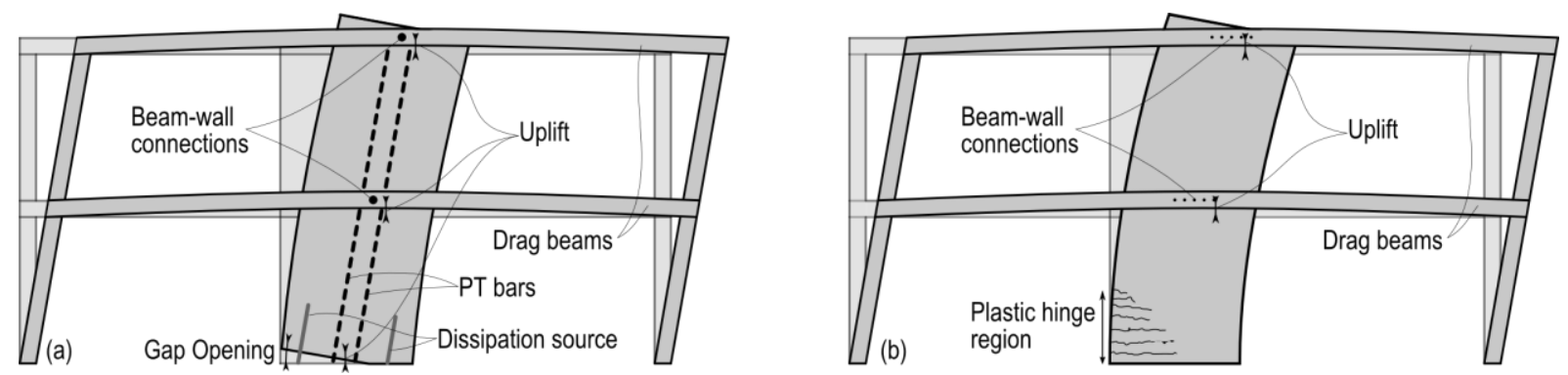

Figure 2. Vertical displacement incompatibly between wall and diaphragm. (a) rocking wall; (b) monolithic concrete wall.

Two alternative design strategies can be adopted to mitigate the effects of vertical displacement incompatibility. A series of different connection options and construction details to connect the diaphragm drag beams to the rocking wall have been proposed and experimentally validated by Moroder et al. (2014b).

According the first design strategy, the displacement incompatibility can be addressed by a careful connection detailing in the design phase;

Recently built Pres-lam buildings provide examples of implementation of the aforementioned alternative connection solutions. The construction detailing of the Nelson and Marlborough Institute of Technology (NMIT) Arts and Media building (Devereux et al., 2011) (S 4116’33” E 17317'16”, Figure 3a) adopted 200mm diameter steel pins, located slightly offset from the centre of the (coupled) post-tensioned walls to avoid the central posttensioning cables. The absence of continuity of the collector beam and the distance between the pins create little restraint in the case of wall uplift. Furthermore, the pin acts as a hinge so that no rotation is imposed on the beam.
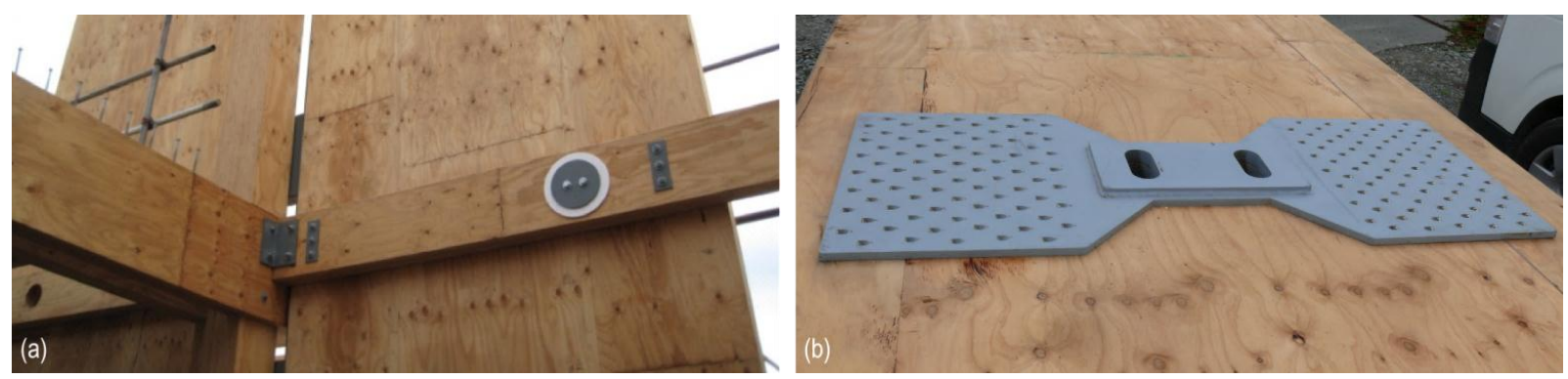

Figure 3. Collector beams connection details (modified from Moroder et al. (2014a). (a) NMIT Arts and Media building (Devereux et al., 2011); (b) Trimble Building (Brown et al., 2012)

Figure $3 \mathrm{~b}$ shows a different connection detail allowing for the relative vertical displacement between the collector beam and the (coupled) post-tensioned shear walls in the Trimble Building (Brown et al., 2012) (S4332’35” E172 35'31”). A steel plate with a vertically slotted hole was attached to the timber wall, a steel plate with a round hole was attached to 
the collector beam and via an interconnecting steel pin, horizontal forces are transferred while allowing for uplift and rotation (Moroder et al., 2014a).

According to the second design strategy, an alternative configuration of the post-tensioned rocking system can be developed such that the uplifting of the wall is not transferred to the diaphragm.

A solution using this approach was developed for precast concrete and tested by Henry et al. (2012a). The system, referred to as PreWEC system (i.e. Precast Wall with End Columns, see Figure 4a), consisted of a precast concrete post-tensioned rocking wall with two steel or concrete end columns that were anchored to the foundation using unbonded post-tensioning (Henry et al., 2012a).

Additional dissipation was provided by mild steel devices referred to as O-connectors; the dissipater is shown in Figure 4b.
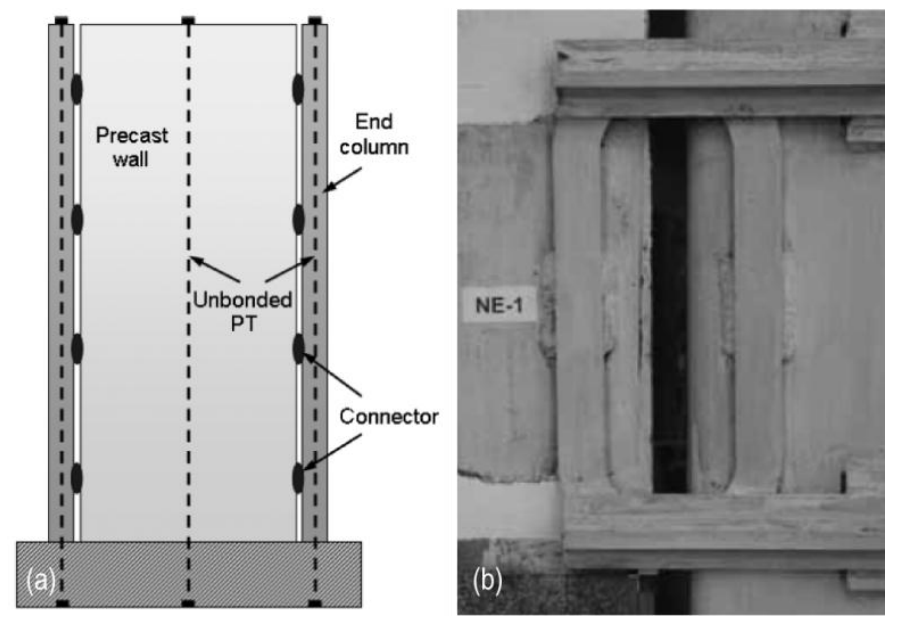

Figure 4. (a) PreWEC system; (b) O-connector (modified after Henry et al. (2012a)).

A similar system is proposed in the paper and extended to timber, and referred to as CWC (Colum-Wall-Column). The boundary columns can be connected at the foundation using either post-tensioning or other timber fasteners (i.e. bolts, screws or rivets).

The columns are coupled to the wall system using U-Shaped Flexural Plates (UFPs) (Skinner et al., 1974) or any other dissipative devices, which provide additional overturning moment contribution as well as energy dissipation.

Although the UFPs couple the different components, they do not have the required strength in their out of plane direction to transfer the horizontal shear (e.g. diaphragm inertia forces) between the different elements. To overcome this, horizontal shear transfer devices are used (see Figure 5). 


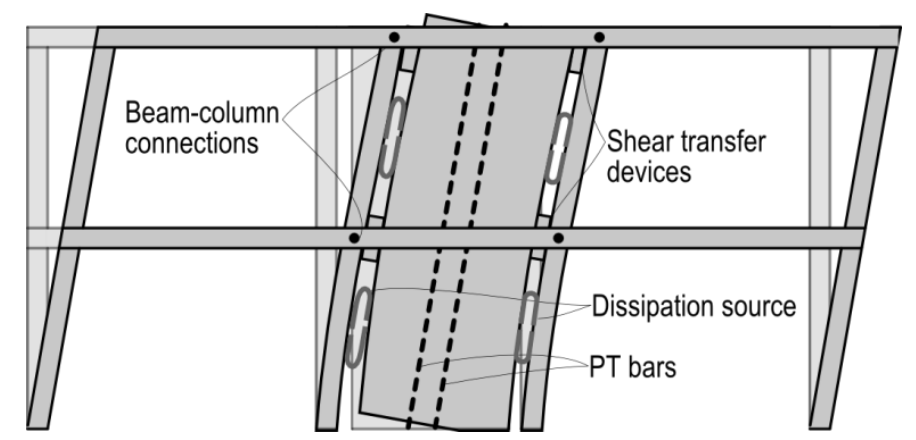

Figure 5. Reduced vertical displacement incompatibility in the CWC system.

The main objectives of the experimental campaign on the CWC system presented in the paper were a) the investigation of the overall seismic behaviour of such system, b) the development of timber-specific system detailing and c) the validation of design and modelling procedures. The paper first presents the design and construction detailing of the specimens, with focus on the dissipaters attachment and the shear transfer devices.

In the second part, the testing program is presented and the experimental results are discussed in terms of global force-displacement behaviour and area-based equivalent viscous damping of the system.

\section{Design of the test specimen}

\section{Seismic Design of full-scale prototype}

The testing specimens were designed as part of three storey prototype building implementing the proposed solution as seismic resistant system. The prototype building (see Figure 6) was a three storey timber construction with an approximate floor area of $600 \mathrm{~m}^{2}$; the ground floor level was assumed to be used for retail purposes, level two as office space and level 3 with residential type loadings.

The building was designed following a Displacement-Based Design approach (Priestley et al., 2007) targeting 1\% design drift and for a soil type D located in the Christchurch CBD hazard factor $(Z=0.3)$ according to NZS1170.5 (Standards New Zealand, 2004). The design results are summarized in Table 1.
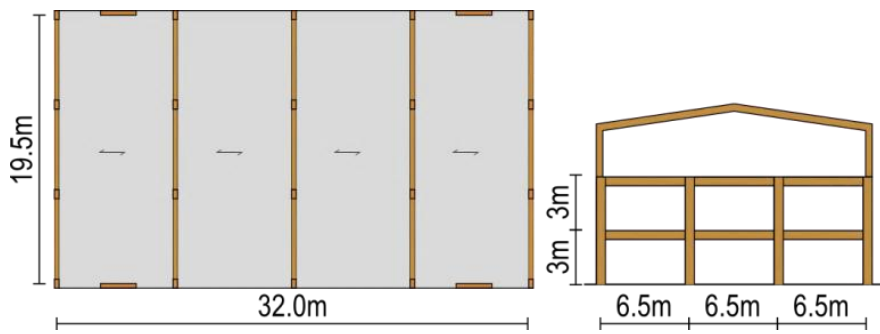

Figure 6. Case study building plan view and elevation. 
Table 1.DBD design parameters and equivalent SDOF structure properties

\begin{tabular}{lr}
\hline Design drift & $1 \%$ \\
Ductility & 2 \\
Damping & $12.9 \%$ \\
Effective design displ. & $0.050 \mathrm{~m}$ \\
Effective mass & $119 \mathrm{t}$ \\
Effective height & $5.0 \mathrm{~m}$ \\
Effective period & $0.85 \mathrm{~s}$ \\
Secant stiffness & $6478 \mathrm{kN} / \mathrm{m}$ \\
Total Base shear & $322 \mathrm{kN}$ \\
Total Base moment & $1604 \mathrm{kNm}$ \\
\hline
\end{tabular}

Due to space constraint in the structural laboratory (i.e. overhead crane clearance), the specimens were tested at $2 / 3$ scale, and the shear and moment demand were scaled according to a constant density approach. The scaled base shear and moment were $143 \mathrm{kN}$ and $475 \mathrm{kNm}$ per wall respectively.

\section{Section analysis}

The section analysis of dissipative post-tensioned rocking sections was carried out using a moment-rotation iterative analysis procedure and Figure 7 reports the nomenclature used in the equations below. The procedure was first developed by Pampanin et al. (2001), refined by Palermo et al. (2005b) and more recently adapted to timber systems by Newcombe et al. (2008).

Before the section decompression occurs, the wall system behaves as a vertical cantilever. Once the decompression moment given by Equation (1) is reached the gap starts opening.

$$
M_{d e c}=\left(N+\sum T_{p t, i}\right) \frac{Z_{t}}{A_{t}}
$$

Where $Z_{t}$ and $A_{t}$ are the timber section modulus and cross-sectional area respectively. For rectangular sections $Z_{t} / A_{t}=h / 6$, where $h$ is the section depth.

The decompression moment indicates the moment necessary to create tension stresses in the section. As the wall is capable of rocking no tension stress is developing in the section, instead some connection rotation occurs and an iterative analysis procedure is necessary. 

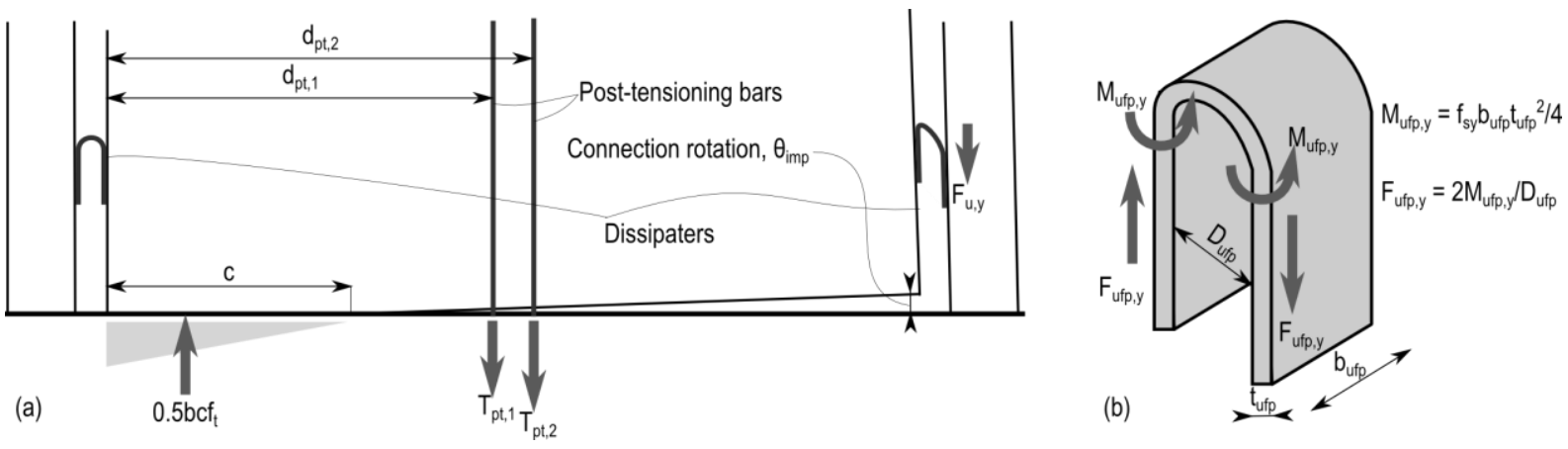

Figure 7. (a) Section nomenclature; (b) UFP yielding mechanism.

For an imposed connection rotation the neutral axis depth, c, is guessed and the posttensioning force in each tendon, $\mathrm{T}_{\mathrm{pt}, \mathrm{i}}$, can be evaluated.

$$
T_{p t, i}=T_{p t 0, i}+\frac{\theta_{i m p}\left(d_{p t, i}-c\right)}{l_{u b}} E_{p t} A_{p t, i}
$$

where $T_{p t 0, i}$ is the initial post-tensioning force in each tendon, $\theta_{\text {imp }}$ the connection rotation, $d_{p t, i}$ is the edge distance of the $\mathrm{i}$-th tendon, $\mathrm{l}_{\mathrm{ub}}$ the post-tensioning bars unbonded length, $\mathrm{E}_{\mathrm{pt}}$ the modulus of elasticity of post-tensioning steel, $\mathrm{A}_{\mathrm{pt}, \mathrm{i}}$ the $\mathrm{i}$-th tendon cross-sectional area.

It must be clarified that the evaluation of the increase in post-tensioning force does not account for any axial deformation of the wall (i.e. axial and bending) since this is generally negligible when compared to the displacement generated by the gap opening.

The dissipaters displacement, $\Delta_{\text {ufp }}$, can be also evaluated as a function of the geometric parameters of the wall as well as the connection rotation and neutral axis depth.

$$
\Delta_{u f p}=\theta_{i m p}(h-c)
$$

Where $\mathrm{h}$ is the section depth.

As shown by experimental tests (Skinner et al., 1974) and numerical analyses carried out by Baird et al. (2014), the force-displacement hysteretic loop of a UFP device can be modelled by a Ramberg-Osgood (Ramberg et al., 1943) as shown in Equation (4).

$$
\Delta_{u f p}=\frac{F_{u f p}}{k_{0}}\left[1+\left(\frac{F_{s}}{F_{u f p}}\right)^{R-1}\right]
$$

Where $F_{s}$ is the force developed in the UFP device and $F_{u f p}$ the UFP yield force given by Equation (5).

$$
F_{u f p}=\frac{f_{s y} b_{u} t_{u}^{2}}{2 D_{u}}
$$


Where $\mathrm{k}_{0}$ the UFP initial stiffness (Equation (6)), $\mathrm{R}$ the Ramberg-Osgood factor (Equation (7)), $b_{\text {ufp }}$ the width of the UFP plate section, $t_{u f p}$ the thickness of the UFP plate section, $D_{\text {ufp }}$ the diameter of UFP plate bend and $\mathrm{E}_{\mathrm{s}}$ the steel elastic modulus.

$$
\begin{aligned}
& k_{0}=\frac{16 E_{s} b_{u f p}}{27 \pi}\left(\frac{t_{u f p}}{D_{u f p}}\right)^{3} \\
& R=7.1 \ln \left(\frac{t_{u f p}}{D_{u f p}}\right)+29.5
\end{aligned}
$$

To evaluate the timber compressive force, $\mathrm{C}_{t}$, a member strain compatibility condition is applied, according to the Modified Monolithic Beam Analogy (MMBA) (Newcombe et al., 2008; Palermo et al., 2008) procedure and the displacement of the rocking element is assumed to be the same as that of the analogic monolithic element.

$$
C_{t}=0.5 E_{c o n} b c^{2}\left(\frac{3 \theta_{i m p}}{L_{c a n t}}+\frac{M_{d e c}}{E_{c o n} I}\right)
$$

Where $\mathrm{E}_{\mathrm{con}}$ is the connection modulus (equal to $0.7 \mathrm{E}_{\mathrm{t}}$ for post-tensioned timber walls), $\mathrm{b}$ the section width, $\mathrm{L}_{\mathrm{cant}}$ the cantilever length (height of the centroid of the applied lateral loads), $\mathrm{M}_{\mathrm{dec}}$ the decompression moment and I the section second moment of area.

The force equilibrium reported in Equation (9) is finally assessed and if this is not satisfied the neutral axis depth must be iterated on.

$$
-C_{t}+n_{u f p} F_{s}+\sum_{i=1}^{n_{p t}} T_{p t, i}=0
$$

Where $\mathrm{n}_{\text {ufp }}$ is the number of UFP devices.

Once the equilibrium is satisfied, the connection moment, $\mathbf{M}_{\mathrm{con}}$, can be evaluated around the timber compression centroid.

$$
\phi M_{c o n}=\phi\left(M_{p t}+M_{s}\right)=\phi\left[\sum_{i=1}^{n_{p t}} T_{p t, i}\left(d_{p t, i}-\frac{c}{3}\right)+n_{u f p} F_{s}\left(h-\frac{c}{3}\right)\right]
$$

Where $\phi$ is the strength reduction factor (Standards New Zealand, 1993) usually taken as 0.9 for Pres-Lam Structures, $M_{p t}$ the post-tensioning moment contribution, $M_{s}$ the dissipative moment contribution (i.e. from UFPs) and $\mathrm{d}_{\mathrm{pt}, \mathrm{i}}$ is the edge distance of the $\mathrm{i}$-th post-tensioning reinforcement.

The section re-centering ratio, $\beta$, is a key parameter in the design of post-tensioned rocking sections defined as the ratio between the post-tensioning moment, $\mathrm{M}_{\mathrm{pt}}$, and the connection moment, $\mathbf{M}_{\mathrm{con}}$, as shown in Equation (11). 
$\beta=\frac{M_{p t}}{M_{c o n}}$

The reinforcement layout of the specimens was designed in order to obtain the same wall capacity as a single wall system, so the preliminary design was carried out neglecting any additional contribution due to the boundary columns. This provided direct comparison with the traditional single wall solution (Sarti et al., 2015).

The benchmark specimen was designed at a wall re-centering ratio of 0.6; as a result, an initial post-tensioning force of $400 \mathrm{kN}$ was applied and 8 UFPs (i.e. 4 on each side of the wall) were connected. The UFPs were $130 \mathrm{~mm}$ wide flat plates (Mild steel Grade350), 12mm thick and bent with a radius of 52mm. Table 2 reports the material properties considered in the design phase and

Table 3 summarizes the connection capacity parameters reported above for each testing specimen.

Table 2. Material structural and geometric properties.

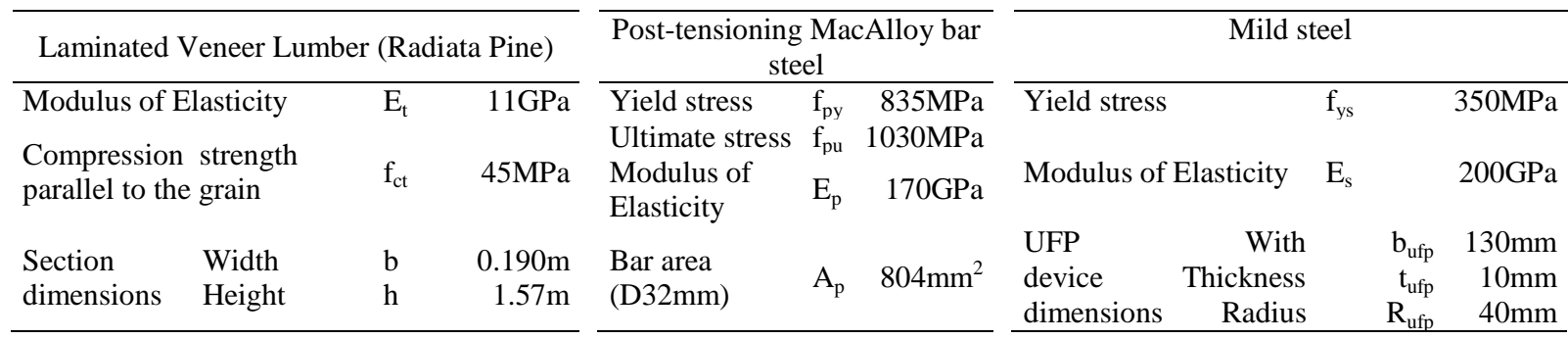

Table 3. Connection capacity summary.

\begin{tabular}{|c|c|c|c|c|c|c|c|c|c|c|c|}
\hline & $\begin{array}{r}\text { Init. PT } \\
\text { Force }\end{array}$ & $\mathbf{n}_{\text {ufp }}$ & $\begin{array}{r}\text { Neut. } \\
\text { Axis }\end{array}$ & $\begin{array}{r}\text { PT } \\
\text { force }\end{array}$ & $\begin{array}{l}\text { UFP } \\
\text { disp. }\end{array}$ & $\begin{array}{l}\text { UFP } \\
\text { force }\end{array}$ & $\begin{array}{r}\text { Timber } \\
\text { Force }\end{array}$ & $\begin{array}{r}\text { PT } \\
\text { moment }\end{array}$ & $\begin{array}{r}\text { Diss. } \\
\text { Moment }\end{array}$ & $\begin{array}{r}\text { Total } \\
\text { Moment }\end{array}$ & $\begin{array}{r}\text { Re-cent. } \\
\text { ratio }\end{array}$ \\
\hline$I D$ & $T_{p t 0}$ & & $c$ & $T_{p t}$ & $\Delta_{u f p}$ & $F_{s}$ & $C_{t}$ & $\phi M_{p t}$ & $\phi M_{s}$ & $\phi M_{c o n}$ & \\
\hline CWC400 & 400 & $\mathrm{n} / \mathrm{a}$ & 317 & 605 & $\mathrm{n} / \mathrm{a}$ & $\mathrm{n} / \mathrm{a}$ & -605 & 385 & 0 & 385 & 1.00 \\
\hline CWC600 & 600 & $\mathrm{n} / \mathrm{a}$ & 359 & 789 & $\mathrm{n} / \mathrm{a}$ & $\mathrm{n} / \mathrm{a}$ & -789 & 487 & 0 & 487 & 1.00 \\
\hline CWC400-8 & 400 & 8 & 350 & 590 & 10 & 146 & -736 & 371 & 192 & 563 & 0.66 \\
\hline CWC400-4 & 400 & 4 & 334 & 597 & 10 & 73 & -670 & 378 & 96 & 474 & 0.80 \\
\hline CWC600-4 & 600 & 4 & 374 & 780 & 10 & 73 & -853 & 479 & 95 & 574 & 0.83 \\
\hline
\end{tabular}

NOTE: the values reported are at the connection rotation $\theta_{\text {imp }}=0.8 \%$ which accounts for the design drift of $1 \%$ and elastic deflection of the cantilever wall of $0.2 \%$. A strength reduction factor $\phi=0.9$ was used.

It is worth noticing that the specimens CWC400-8 and CWC600-4 were designed to target the same capacity with a different re-centering ratio. The post-tensioned only configurations were tested to provide information on the friction contribution from the shear transfer devices.

\section{Discussion on post-tensioning losses}

Due to its peculiar structure, timber is subjected to dimensional variations which can be caused by a number of factors such as thermal and relative humidity variations, as well as creep. 
As shown in the previous section, the post-tensioning force is a major design parameter and possible post-tensioning losses shall be accounted for in the initial design phase of the structural element.

Experimental tests on post-tensioned LVL beams were carried out by Davies et al. (2011). The test results of the specimens loaded in the parallel to the grain direction only highlighted losses of $1.4 \%$ and $1.5 \%$ for respectively pure creep and mechano-sorption creep over a 1 year period. The total post-tensioning loss of $2.9 \%$ was approximately extrapolated of a 50 years period assumed service life and resulted in between 6 and 10\% (Davies et al., 2011).

Some analytical prediction methods were also developed (Giorgini et al., 2010; Fragiacomo et al., 2011) enabling the prediction of post-tensioning losses.

\section{Test specimen detailing}

\section{Dissipaters}

U-shaped Flexural Plates were used as coupling and dissipation devices. In general, UFPs are connected to the wall edges were the maximum relative displacement between adjacent elements is developed. In order to create a connection that allowed the replacement of the dissipation devices after testing, a steel assembly was fabricated and fastened to the wall and the column using timber rivets (see Figure 8 ). The rivets were $90 \mathrm{~mm}$ long and the crosssection was $3.2 \times 6.4 \mathrm{~mm}$.

Two $6 \mathrm{~mm}$ thick steel plates with rows of several $10 \mathrm{~mm}$ plain holes were welded on the sides of a $20 \mathrm{~mm}$ thick plate as shown in Figure 8 . The thicker plate provided the connection plate for the UFP device via M16 metric threaded holes. Once the wall and columns were positioned, the UFPs could be placed into position and bolted to the coupled elements. 

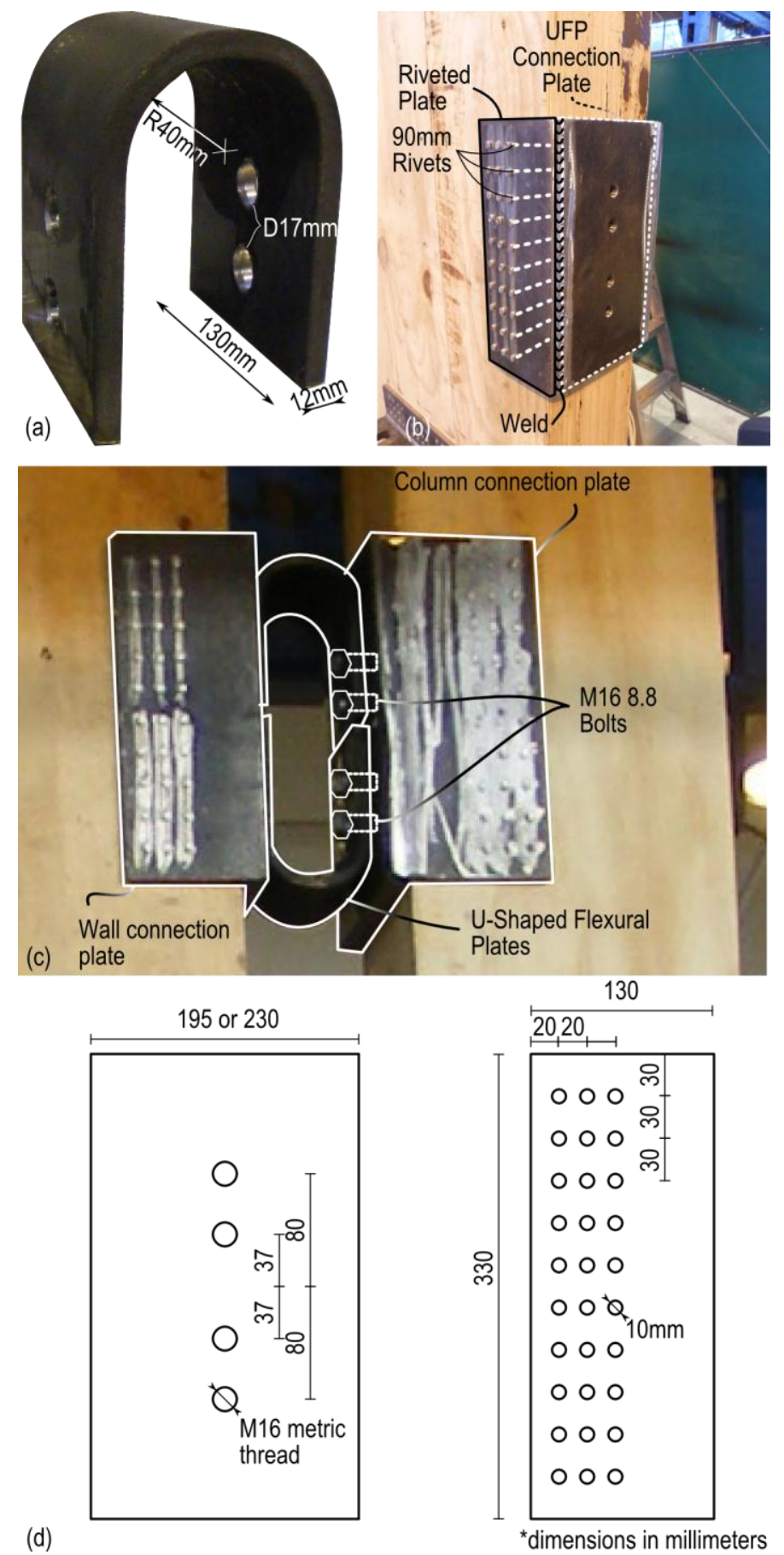

Figure 8. UFP connection: (a) U-shaped Flexural Plate details; (b) detail of the welded connection and riveted plates; (c) detail of the final setup; (d) Technical details of the connection plate.

\section{Shear transfer blocks}

Whilst UFPs are a suitable way to provide wall coupling as well as dissipation, the low stiffness and strength in the transverse direction of the dissipaters is insufficient to allow using the device to transfer the horizontal shear (i.e. diaphragm forces) between the different components of the system. 
Since the relative displacement between the coupled elements is a key feature for the correct functioning of the system, the horizontal forces need to be transferred using sliding devices.

Using such a solution, some friction was expected to develop between the shear transfer device and the wall. Although this friction contribution may increase the dissipative contribution of the system (i.e. higher hysteretic damping), this is not usually easy to evaluate nor should it be relied upon in the design phase unless a specific quality controlled friction device (possibly in combination with, or as an alternative to, the UFP) was used. Moreover, it should be remembered that a significant friction contribution could affect the overall system behaviour, reducing the re-centering capabilities and thus could lead to some residual displacements after testing (or seismic event).

As a design choice, the shear transfer device was fabricated to minimize the friction force developed by the sliding of the transfer block and the wall panel.

The shear transfer block was a Laminated Veneer Lumber (LVL) element connected to the column through inclined self-tapping screws (see Figure 9c,d). A 20mm thick High-Density Polyethylene (HDPE) sheet was screwed to the block's surface and thin stainless steel plates were fixed to the edge of the wall panel as shown in Figure 9b. Figure 9d shows the screw connection layout.
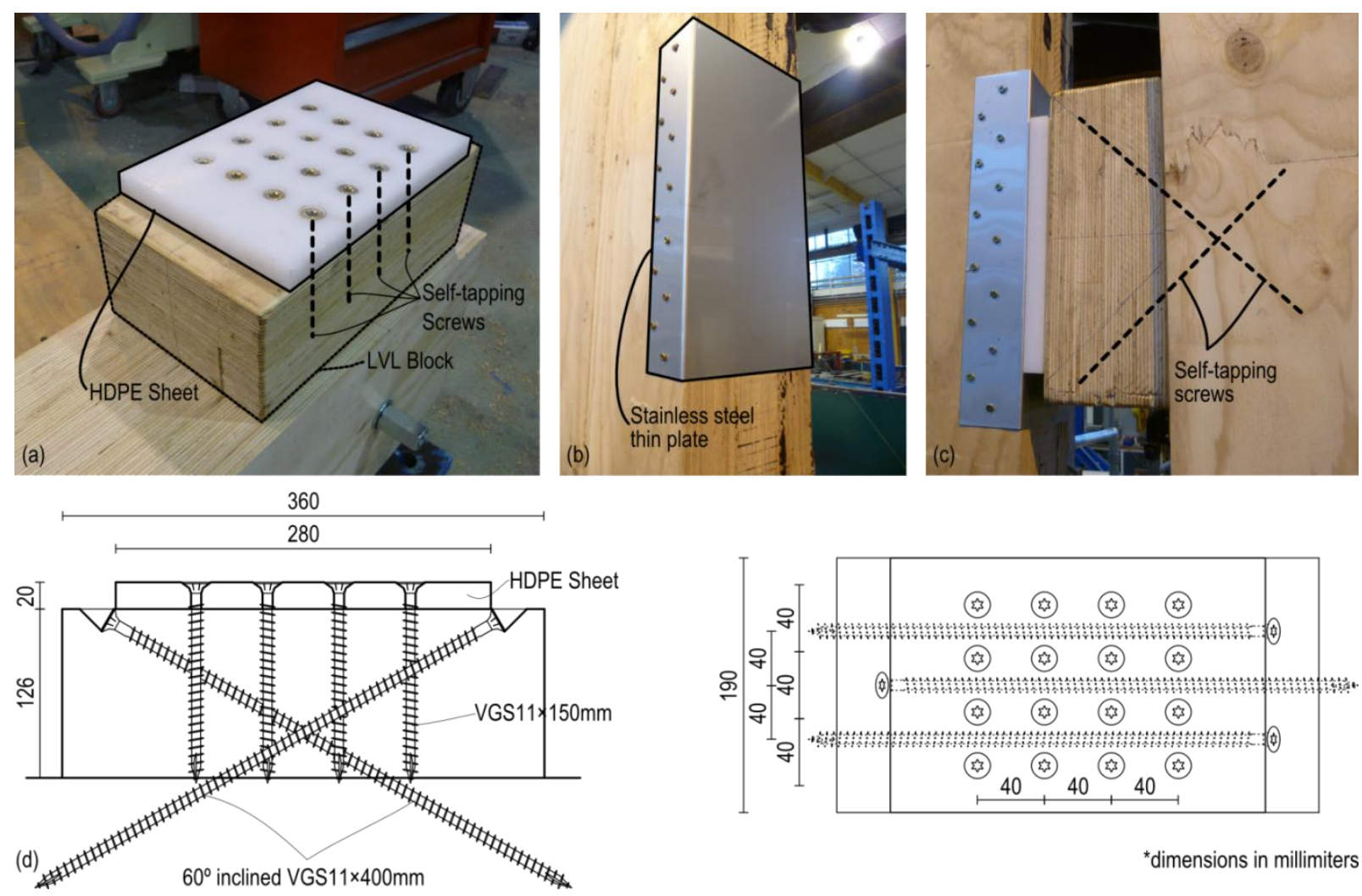

Figure 9. Shear transfer device. (a) LVL and HDPE block on the column; (b) Stainless steel sheet on the wall edge; (c) completed setup; (d) screw layout details. 


\section{Testing program}

The testing schedule (Table 4) consisted of several reinforcing configurations, starting with a number of post-tensioned only specimens (i.e. non-linear elastic behaviour was expected) with $400 \mathrm{kN}$ and $600 \mathrm{kN}$ initial post-tensioning loads. The main purpose of the post-tensioned only tests was to capture the friction contribution of the shear transfer devices.

After testing the post-tensioned only specimens, the wall and side column elements were coupled with UFPs and different layouts were implemented to investigate the influence of the re-centering ratio $\left(\beta=\mathrm{M}_{\mathrm{pt}} / \mathrm{M}_{\mathrm{tot}}\right)$.

Table 4.Post-tensioned walls testing schedule.

\begin{tabular}{cccc}
\hline Test ID & PT Initial & UFPs & $\begin{array}{c}\text { Wall Re-centering } \\
\text { Ratio, } \boldsymbol{\beta}\end{array}$ \\
\hline CWC400 & $400 \mathrm{kN}$ & $\mathrm{n} / \mathrm{a}$ & 1.00 \\
CWC600 & $600 \mathrm{kN}$ & $\mathrm{n} / \mathrm{a}$ & 1.00 \\
CWC400-8 & $400 \mathrm{kN}$ & 8 & 0.66 \\
CWC400-4 & $400 \mathrm{kN}$ & 4 & 0.80 \\
CWC600-4 & $600 \mathrm{kN}$ & 4 & 0.83 \\
\hline
\end{tabular}

The specimen representing a structural system with two suspended floors was loaded using a triangular lateral force distribution to simulate the inertia forces associated with a first mode of vibration of the case study. This was achieved using a load distribution beam as shown in Figure 10. The load distribution beam had two pins spaced $2 \mathrm{~m}$ and connected to the specimen with steel plates and threaded rods. The ram was connected using a third pin located at $1.36 \mathrm{~m}$ from the bottom pin of the distribution (see Figure 10).

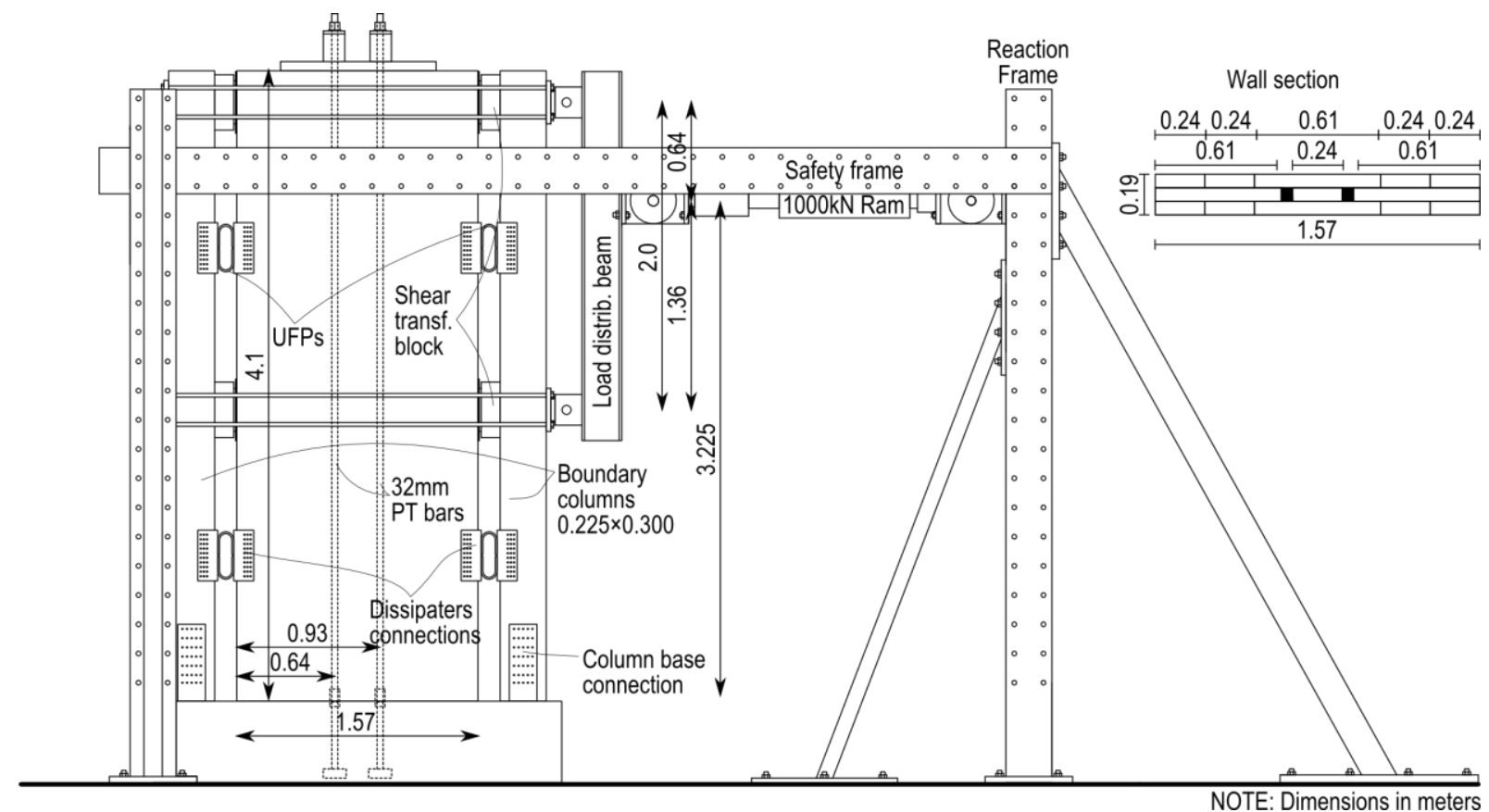

Figure 10. Test setup. 
The ram was connected to the load distribution beam and to the reaction frame through universal joints. The reaction frame was fabricated using a steel column (double 300PFC profile) and laterally stabilized by two steel struts (SHS100 and SHS200) as shown in Figure 10.

The load was applied by a hydraulic actuator with a $1000 \mathrm{kN}$ load cell at mounted at a height of $3.7 \mathrm{~m}$ from the strong floor $(3.225 \mathrm{~m}$ from the bottom of the wall).

Since universal joints were used to avoid the development of moment to the hydraulic actuator, the out of plane displacement of the specimen was not restrained. Therefore, a safety frame was constructed to avoid displacements in the wall transverse direction.

The quasi-static displacement protocol (Figure 11b) consisted of a series of displacementcontrolled cycles at increasing levels of amplitude according to the ACI ITG-5.1-07 protocol (ACI Innovation Task Group 5, 2008). The maximum displacement of the first three cycles did not exceed $60 \%$ of the design displacement $(0.040 \mathrm{~m})$ and the maximum displacement of the subsequent cycles was between 1.25 and 1.5 times the previous maximum displacement. A maximum top drift of $2 \%$ was imposed.

\section{Instrumentation}

The displacement at the top of the wall was recorded and at the top of the wall and controlled by feedback from the rotary potentiometer D (see Figure 11a). The applied load as well as the post-tensioning forces was recorded using $1000 \mathrm{kN}$ load cells, referred to as LC, PT1 and PT2, respectively, and shown in Figure 11.
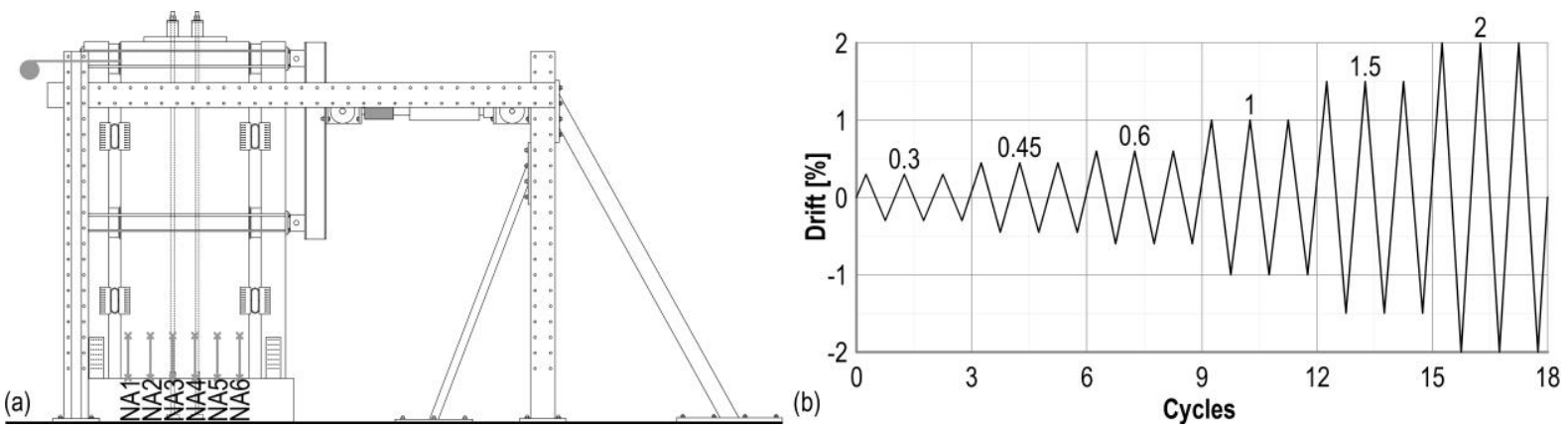

Figure 11. (a) Instrumentation setup; (b) testing protocol (ACI Innovation Task Group 5, 2008).

The variation of the compressive region depth was measured by the neutral axis depth. Several spring-loaded potentiometers (NA1 to NA6) were positioned at the wall base at different spacing to record the uplift of the rocking section along the section depth. This setup also enabled the evaluation of the compressive region (neutral axis) depth and of the connection rotation. The recorded displacement profile was fitted using a linear function, 
with the slope and zero of such function identifying the connection rotation and neutral axis depth respectively.

\section{Experimental results}

\section{Post-tensioned only specimens}

The tests results from pure post-tensioning rocking specimens are shown in Figure 12 for two different post-tensioning initial forces (i.e. $400 \mathrm{kN}$ and $600 \mathrm{kN}$ ).
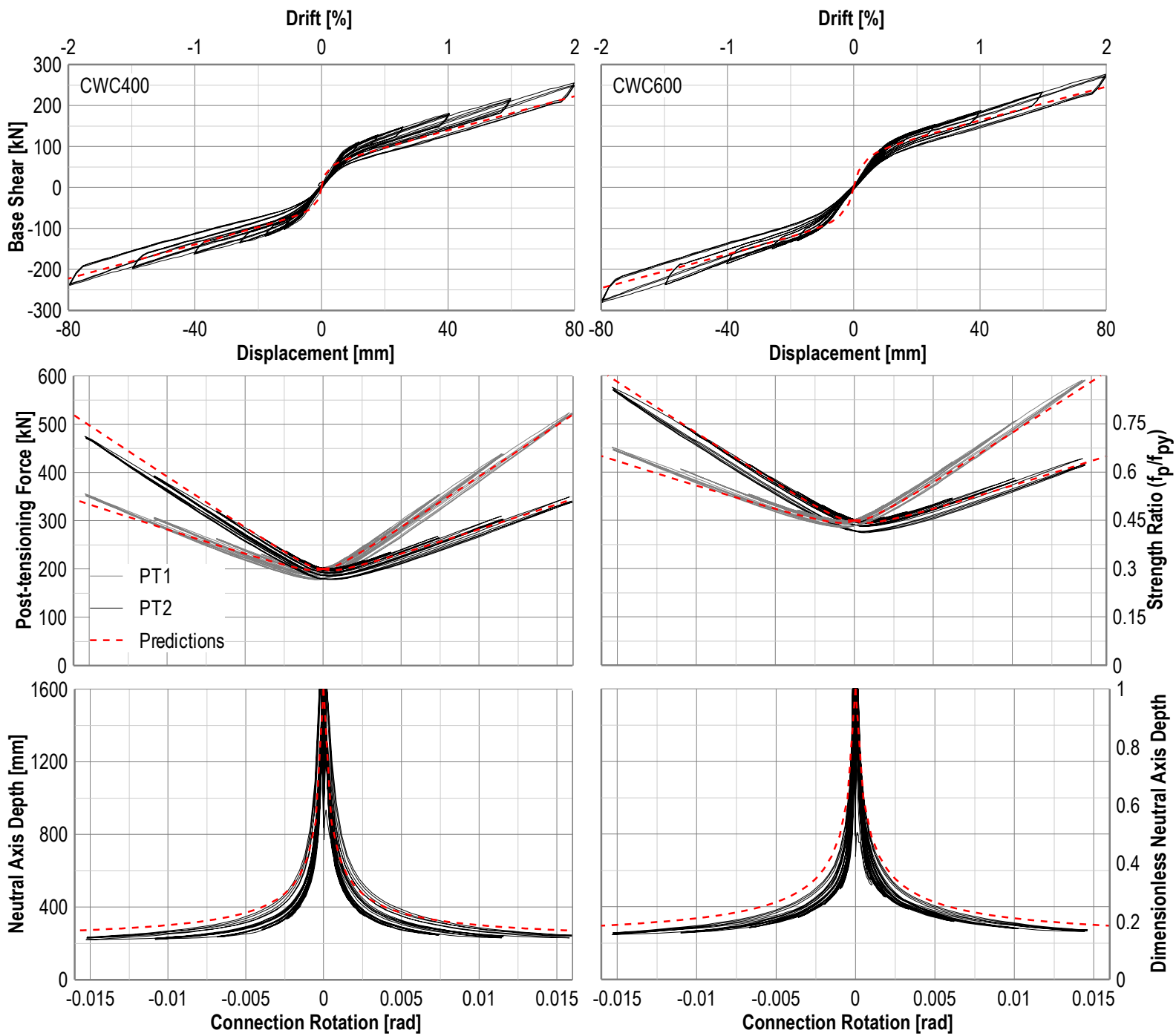

Figure 12. Pure post-tensioned rocking experimental results (continuous line) vs. analytical predictions

(dashed line)

As expected, before the decompression point is reached, the global force-displacement behaviour is that typical of a cantilever system with fixed base.

Although a post-tensioned only rocking solution would be expected to display a non-linear elastic behaviour, an additional contribution from the shear transfer devices between columns and walls was expected. This can be observed in the force-displacement loops of Figure 12, 
where the system shows the development of a small hysteretic area due to the friction force developed.

The sliding friction contribution to the total moment was evaluated in terms of re-centering ratio. Figure 13a shows the plots of the re-centering ratio, $\beta$, as defined in Equation (11), versus the connection rotation as evaluated from the experimental data. The charts are shown for both the post-tensioned only CWC specimens. In general a decreasing trend is observed for increasing drifts. The experimental values show asymptotic values of about 0.9 and 0.95 , which suggests friction contributions of $10 \%$ and 5\% for CWC400 and CWC600 specimens respectively.

The experimental results were also compared to the analytical formulas, and the total moment was evaluated by Equation (12).

$$
M_{t o t}=M_{p t}+M_{s}+M_{c}
$$

Where $\mathrm{M}_{\mathrm{c}}$ is the moment contribution of the columns given in Equation (13).

$$
M_{c}=\frac{\Delta}{L}\left(\frac{1}{k_{\theta}}+\frac{7 L}{48 E I_{c}}\right)^{-1}
$$

Where $\Delta$ is the wall top displacement, $\mathrm{L}$ the length of the column, $\mathrm{k}_{\theta}$ the rotational stiffness of the column connection, $\mathrm{E}$ the timber modulus of elasticity and $\mathrm{I}_{\mathrm{c}}$ the column's second moment of area.

The charts in Figure 12 show that post-tensioning force and neutral axis depth analytical results fit the experimental observed data. A minor under-estimation of the forcedisplacement backbone curve was noticed. This resulted by neglecting the friction force developed in the shear transfer blocks.

Figure 13b-c shows a comparison of the experimental results of CWC system with the posttensioned single wall option ( 4400 , i.e. post-tensioned only solution at $400 \mathrm{kN}$ initial posttensioning force) as previously tested by the authors (Sarti et al., 2015). While the momentrotation chart demonstrates the additional dissipative contribution due to the shear transfer blocks (5 to $10 \%$ of the total moment), the neutral axis depth (Figure 13c) is not significantly affected by the additional axial contribution developed in the shear transfer device.

The comparison between the alternative system and a more traditional single wall configuration highlights that the two systems can be designed to be equivalent with no apparent major differences in terms of the seismic response. However, the CWC system has the significant advantage of avoiding displacement incompatibility issues thus allowing the diaphragm damage avoidance. 

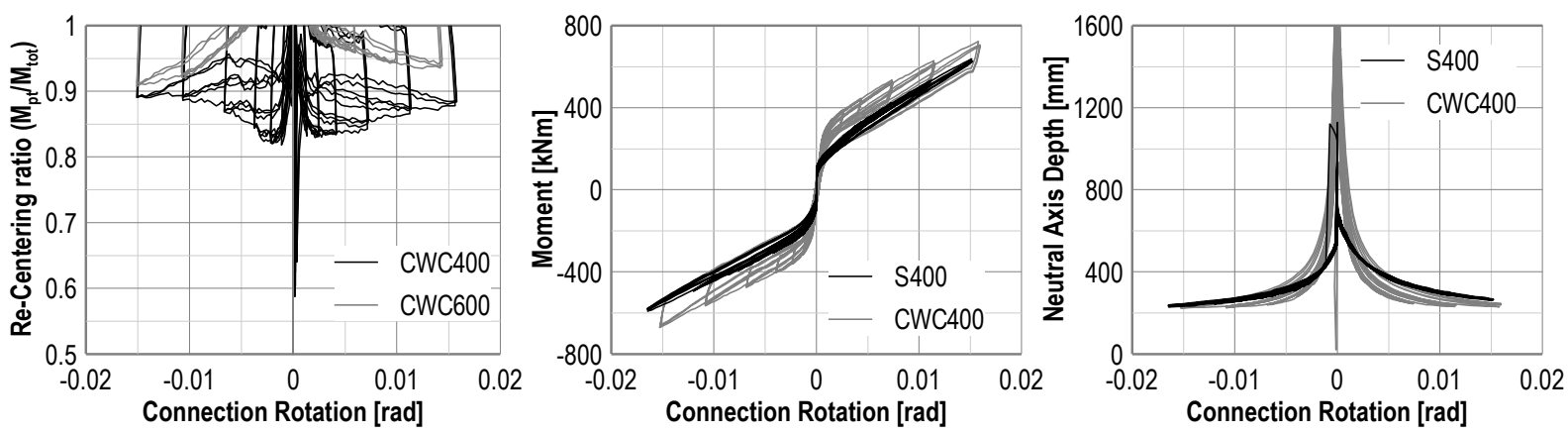

Figure 13. Comparison of CWC vs. Single Wall equivalent (a) Re-centering ratio vs. connection rotation.

Comparison with single wall options: (b) moment and (c) neutral axis depth versus rotation.

\section{Rocking/Dissipative (hybrid) specimens}

After testing the post-tensioned only configuration, U-shaped Flexural plates were added to the system in different configurations.

As highlighted by the experimental results shown in Figure 14, all the specimens displayed a stable hysteresis. Yet, the contribution of the UFPs was not significant in terms of hysteretic area-based damping. The effect of the boundary columns on the shape of the forcedisplacement loops can be highlighted by distinguishing the elastic contributions of the columns from the overall behaviour as shown in the wall moment-rotation charts of Figure 14. The moment-rotation charts of the wall better highlight the difference between the different options showing, as expected, a larger hysteretic area for the specimen CWC400-8 designed with the lowest re-centering ratio.

Unlike tension-compression yield dissipaters (Sarti et al., 2013), U-shaped flexural plates do not show any isotropic strain hardening. This effect is reflected in the experimental results of Figure 14 which highlights that no significant force increase occurred in the unloading branch of the hysteresis where the clamping action from the post-tensioned tendons yields in compression the U-shape flexural plates closing the gap.

Similarly to the single post-tensioned wall configurations (Sarti et al., 2015) the base sheardisplacement loops highlight some stiffness degradation. This is assumed to be due to some connection flexibility of the riveted steel anchorage assembly as well as ratcheting in the dissipaters. 

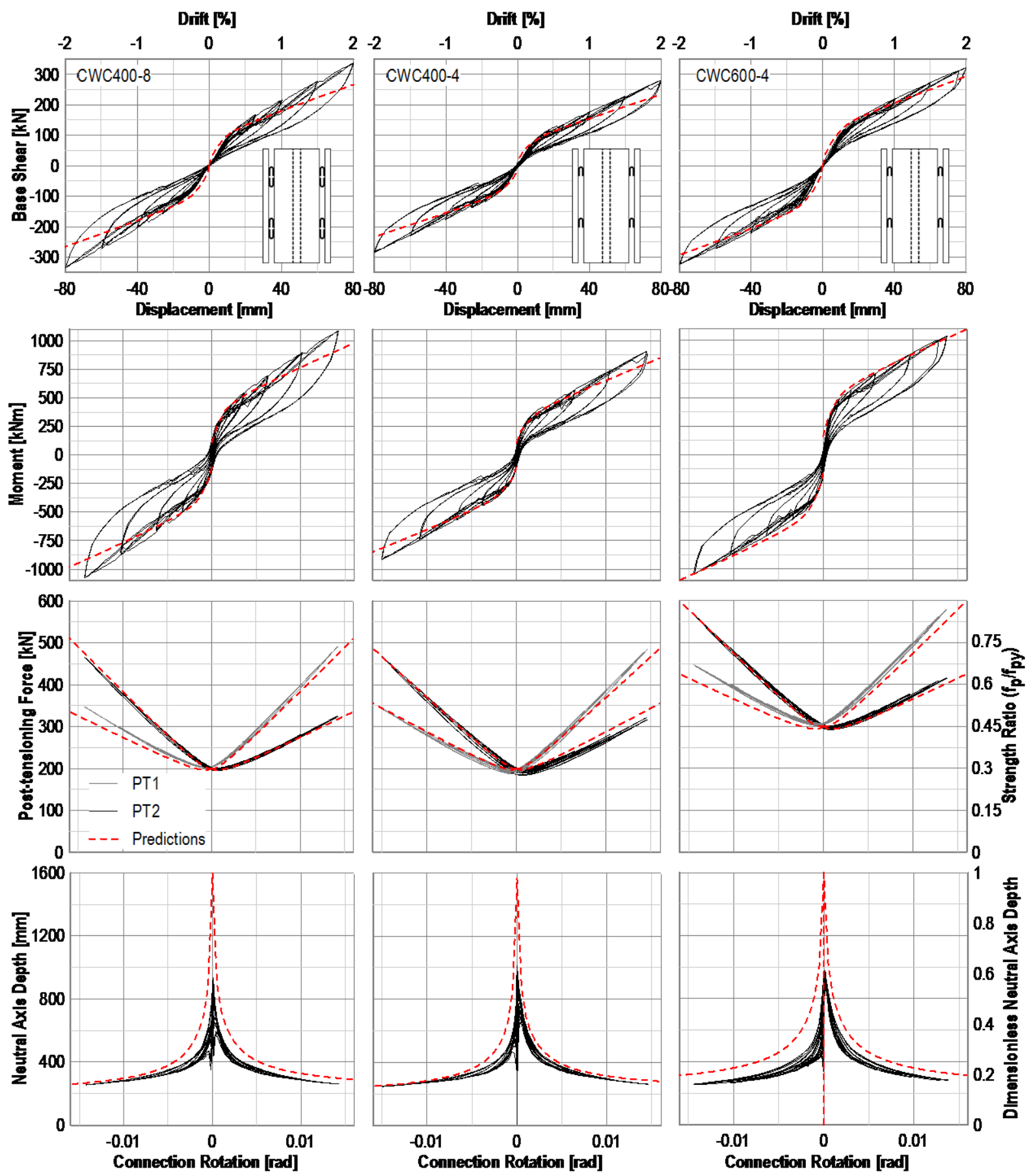

Figure 14. Dissipative post-tensioned rocking experimental results.

As shown in Figure 15, while the dissipaters generally undergo significant tension (positive) displacements, they do not deform into net negative displacement. This causes the dissipaters to develop lower forces, for the same level of displacement, during their re-loading.

As an example, Figure 15 shows the analytical force-displacement loop of the UFP used in the experimental setup. It can be noted that the force developed at $4 \mathrm{~mm}$ at first loading is $30 \mathrm{kN}$, while after load reversal and full reloading is only $21 \mathrm{kN}$. 


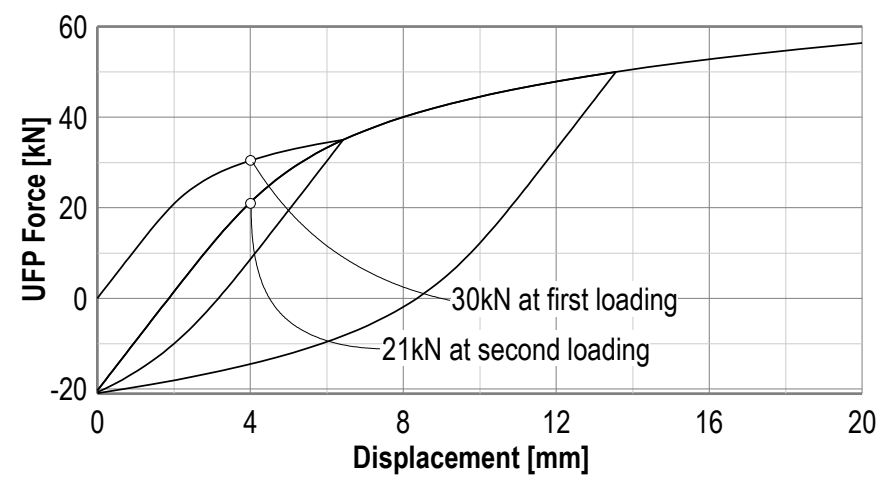

Figure 15. Dissipater's ratcheting behaviour.

Similarly to Section 0 the analytical-experimental comparison showed that the procedure discussed in Section 0 fit relatively well the neutral axis depth and the post-tensioning forces. Similarly to the post-tensioned only solutions the moment-rotation and force-displacement backbone curves are slightly under-predicted at higher drifts as the friction force developed from the shear transfer blocks was neglected.

\section{Conclusions}

While dissipative post-tensioned timber walls are a structurally efficient and robust seismic resisting system for multi-storey buildings, the uplifting coming from the gap opening may cause damage to the floor diaphragm.

The issue can be addressed using either a careful design of the diaphragm connections (Moroder et al., 2014b) or using an alternative wall configuration which minimizes displacement incompatibilities.

The paper presented the design, detailing and testing of an alternative Colum-Wall-Column (CWC) system for the mitigation of displacement incompatibilities in the diaphragm.

The experimental campaign consisted of several wall layouts considering different initial post-tensioning stress levels as well as dissipative devices configurations.

The experimental results on the new alternative system highlighted the flexibility and good performance of the system. All the specimens tested displayed a stable force-displacement response and the development of significant energy dissipation.

Some minor stiffness degradation was observed due to ratcheting in the dissipaters, yet its influence of the overall response (force-displacement) of the system was negligible; however, the stiffness degradation caused a reduction of equivalent viscous damping which was experimentally evaluated. An average value of 0.75 for such reduction factor was found. 


\section{Acknowledgements}

The experimental campaign was funded by the Structural Timber Innovation Company. The technical support of Mosese Fifita and Daniel Moroder is also gratefully acknowledged.

\section{References}

ACI Innovation Task Group 5 2008. Acceptance criteria for special unbonded post-tensioned precast structural walls based on validation testing and commentary : an ACI standard. Farmington Hills, Mich., American Concrete Institute.

Baird, A., Smith, T., Palermo, A., Pampanin, S. 2014. Experimental and Numerical Study of UShaped Flexural Plate (UFP) Dissipators. New Zealand Society for Earthquake Engineering Annual Conference, Auckland, New Zealand.

Brown, A., Lester, J., Pampanin, S., Pietra, D. 2012. Pres-Lam in practice - A damage-limiting rebuild project. New Zealand Society of Structural Engineers Conference, Auckland, New Zealand.

Ceccotti, A. 2008. New Technologies for Construction of Medium-Rise Buildings in Seismic Regions: The XLAM Case. Structural engineering international : journal of the International Association for Bridge and Structural Engineering (IABSE) 18(2): 156-165.

Ceccotti, A., Follesa, M., Lauriola, M.P., Sandhaas, C. 2006a. Sofie project - test results on the lateral resistance of cross-laminated wooden panels. First European Conference on Earthquake Engineering and Seismology, Geneva, Switzerland.

Ceccotti, A., Follesa, M., Lauriola, M.P., Sandhaas, C., Minowa, C., Yasumura, M. 2006b. Which Seismic Behaviour Factor for Multi-Storey Buildings made of Cross-Laminated Wooden Panels? Meeting of the Working Commission W18-Timber Structures, CIB, Florence, Italy.

Ceccotti, A., Sandhaas, C., Okabe, M., Yasumura, M., Minowa, C., Kawai, N. 2013. SOFIE project 3D shaking table test on a seven-storey full-scale cross-laminated timber building. Earthquake Engineering \& Structural Dynamics 42(13): 2003-2021.

Christopoulos, C., Filiatrault, A., Uang, C.M., Folz, B. 2002. Post-tensioned Energy Dissipating Connections for Moment Resisting Steel Frames. Journal of Structural Engineering 128(9): 11111120. 
Davies, M., Fragiacomo, M. 2011. Long-term behavior of prestressed LVL members. I: Experimental tests. Journal of Structural Engineering 137(12): 1553-1561.

Deam, B. 1996. The seismic design and behaviour of multi-storey plywood sheathed timber framed shearwalls. Doctor of Philosophy, University of Canterbury.

Devereux, C., Holden, T., Buchanan, A., Pampanin, S. 2011. NMIT Arts \& Media Building-Damage Mitigation Using Post-tensioned Timber Walls.

Dujic, B., Strus, K., Zarnic, R., Ceccotti, A. 2010. Prediction of Dynamic Response of a 7-Storey Massive Xlam Wooden Building Tested on a Shaking Table. World Conference on Timber Engineering, Riva del Garda, Trentino, Italy.

Dunbar, A., Pampanin, S., Palermo, A., Buchanan, A. 2014. Seismic design of core-walls for multistorey timber buildings. New Zealand Society for Earthquake Engineering Annual Conference, Auckland, New Zealand.

Durham, J., Lam, F., Prion, H. 2001. Seismic Resistance of Wood Shear Walls with Large OSB Panels. Journal of Structural Engineering 127(12): 1460-1466.

Fenwick, R., Megget, L. 1993. Elongation and load deflection characteristics of reinforced concrete members containing plastic hinges. Bulletin of the New Zealand National Society for Earthquake Engineering 26(1): 28-41.

fib 2003. Seismic design of precast concrete building structures: state-of-art report. Lausanne, Switzerland, Fédération internationale du béton, Bulletin n. 23 (Chairmen R. Park, F. Watanabe).

Filiatrault, A., Christovasilis, I., Wanitkorkul, A., van de Lindt, J. 2009. Experimental Seismic Response of a Full-Scale Light-Frame Wood Building. Journal of Structural Engineering 136(3): 246-254.

Fragiacomo, M., Davies, M. 2011. Long-Term Behavior of Prestressed LVL Members. II: Analytical Approach. Journal of Structural Engineering 137(12): 1562-1572.

Gavric, I., Fragiacomo, M., Ceccotti, A. 2015. Cyclic behaviour of typical metal connectors for crosslaminated (CLT) structures. Materials and Structures 48(6): 1841-1857. 
Germano, F., Metelli, G., Giuriani, E. 2015. Experimental results on the role of sheathing-to-frame and base connections of a European timber framed shear wall. Construction and Building Materials 80(0): 315-328.

Giorgini, S., Neale, A., Palermo, A., Carradine, D., Pampanin, S., Buchanan, A.H. 2010. Predicting Time Dependent Effects in Unbonded Post-tensioned Timber Beams and Frames. Meeting of the Working Commission W18-Timber Structures, CIB, Nelson, New Zealand.

Gupta, A.K., Kuo, G.P. 1987. Wood-Framed Shear Walls with Uplifting. Journal of Structural Engineering 113(2): 241-259.

Henry, R., Aaleti, S., Sritharan, S., Ingham, J. 2012a. Seismic Analysis of a Low-Damage Precast Wall with End Columns (PreWEC) Including Interaction with Floor Diaphragms. Journal of the Structural Engineering Society of New Zealand 25(1): 69-81.

Henry, R., Ingham, J., Sritharan, S. 2012b. Wall-to-floor interaction in concrete buildings with rocking wall systems. New Zealand Society of Earthquake Engineering Conference.

Holden, T., Restrepo, J., Mander, J. 2003. Seismic Performance of Precast Reinforced and Prestressed Concrete Walls. Journal of Structural Engineering 129(3): 286-296.

Iqbal, A., Pampanin, S., Fragiacomo, M., Palermo, A., Buchanan, A. 2012. Seismic response of posttensioned LVL walls coupled with plywood sheets. World Conference on Timber Engineering, Auckland, New Zealand.

Källsner, B., Girhammar, U. 2009. Analysis of fully anchored light-frame timber shear walls—elastic model. Materials and Structures 42(3): 301-320.

Karacabeyli, E., Dolan, J., Ceccotti, A., Ni, C., Dinehart, D., Shenton Iii, H. 1999. Comparison of Static and Dynamic Response of Timber Shear Walls. Journal of Structural Engineering 125(7): 796-799.

Kirkham, W., Gupta, R., Miller, T. 2013. State of the Art: Seismic Behavior of Wood-Frame Residential Structures. Journal of Structural Engineering 140(4): 04013097.

Kurama, Y., Sause, R., Pessiki, S., Lu, L.-W. 1999. Lateral load behavior and seismic design of unbonded post-tensioned precast concrete walls. ACI Structural Journal 96(4). 
Kurama, Y.C. 2000. Seismic design of unbonded post-tensioned precast concrete walls with supplemental viscous damping. ACI Structural Journal 97(4).

Kurama, Y.C. 2002. Hybrid post-tensioned precast concrete walls for use in seismic regions. PCI journal 47(5): 36-59.

Marriott, D.J., Pampanin, S., Bull, D., Palermo, A. 2008. Dynamic Testing of Precast, Post-Tensioned Rocking Wall Systems with Alternative Dissipating Solutions. Bulletin of the New Zeland Society for Eartquake Engineering 41(2): 90-103.

Morgen, B.G., Kurama, Y.C. 2007. Seismic Design of Friction-Damped Precast Concrete Frame Structures. Journal of Structural Engineering 133(11): 1501-1511.

Moroder, D., Sarti, F., Palermo, A., Pampanin, S., Buchanan, A. 2014a. Experimental investigation of wall-to-floor connections in post-tensioned timber buildings. New Zealand Society for Earthquake Engineering Annual Conference, Auckland, New Zealand.

Moroder, D., Sarti, F., Palermo, A., Pampanin, S., Buchanan, A. 2014b. Seismic design of floor diaphragms in post-tensioned timber buildings. World Conference on Timber Engineering, Quebec City, Canada.

Newcombe, M.P., Pampanin, S., Buchanan, A.H., Palermo, A. 2008. Section Analysis and Cyclic Behavior of Post-Tensioned Jointed Ductile Connections for Multi-Story Timber Buildings. Journal of Earthquake Engineering.

Palermo, A., Pampanin, S. 2008. Analysis and simplified design of precast jointed ductile connections. World Conference on Earthquake Engineering, Beijing, China.

Palermo, A., Pampanin, S., Buchanan, A.H. 2006. Experimental Investigations on LVL seismic resistant wall and frame subassemblies. First European Conference on Earthquake Engineering and Seismology, Geneva, Switzerland.

Palermo, A., Pampanin, S., Buchanan, A.H., Newcombe, M.P. 2005a. Seismic design of multi-storey buildings using laminated veneer lumber (LVL). New Zealand Society of Earthquake Engineering, Annual Conference, Wairakei, New Zealand, University of Canterbury. Civil Engineering. 
Palermo, A., Pampanin, S., Carr, A. 2005b. Efficiency of Simplified Alternative Modeling Approaches to predict the Seismic Response of Precast Concrete Hybrid Systems. fib Symposium: Keep Concrete Attractive, Budapest, Hungary.

Pampanin, S., Priestley, M.J.N., Sritharan, S. 2001. Analytical modelling of the seicmic behaviour of precast concrete frames designed with ductile connections. Journal of Earthquake Engineering 5(3): 329-367.

Priestley, M.J.N. 1991. Overview of PRESSS research program. PCI Journal 36(4): 50-57.

Priestley, M.J.N., Calvi, G.M., Kowalsky, M.J. 2007. Displacement-based seismic design of structures, IUSS Press.

Priestley, M.J.N., Sritharan, S., Conley, J.R., Pampanin, S. 1999. Preliminary results and conclusions from the PRESSS five-story precast concrete test building. Pci Journal 44(6): 42-+.

Ramberg, W., Osgood, W.R. 1943. Description of stress-strain curves by three parameters, National advisory committee for aeronautics.

Sarti, F., Palermo, A., Pampanin, S. 2015. Quasi-static cyclic testing of 2/3 scale unbonded posttensioned rocking/dissipative timber walls. Journal of Structural Engineering.

Sarti, F., Smith, T., Palermo, A., Pampanin, S., Carradine, D.M. 2013. Experimental and analytical study of replaceable Buckling-Restrained Fused-type (BRF) mild steel dissipaters. New Zealand Society for Earthquake Engineering Annual Conference, Wellington, New Zealand.

Skinner, R.I., Kelly, J.M., Heine, A.J. 1974. Hysteretic dampers for earthquake-resistant structures. Earthquake Engineering \& Structural Dynamics 3(3): 287-296.

Smith, T., Ludwig, F., Pampanin, S., Fragiacomo, M., Buchanan, A., Deam, B., Palermo, A. 2007. Seismic Response of Hybrid-LVL Coupled Walls Under Quasi-Static and Pseudo-Dynamic Testing. NZSEE Conference.

Smith, T., Ponzo, F.C., Di Cesare, A., Pampanin, S., Carradine, D., Buchanan, A.H., Nigro, D. 2013. Post-Tensioned Glulam Beam-Column Joints with Advanced Damping Systems: Testing and Numerical Analysis. Journal of Earthquake Engineering 18(1): 147-167.

Standards New Zealand 1993. AS/NZS 3603. 
Standards New Zealand 2004. AS/NZS 1170.5: Structural Design Actions - Part 5: Earthquake actions.

Stanton, J.F., Hawkins, N.M., Hicks, T.R. 1991. PRESSS Project 1.3: Connection Classification and Evaluation. PCI journal 36(5): 62.

Stewart, W. 1987. The seismic design of plywood sheathed shear walls. Docor of Philosophy, University of Canterubry.

van de Lindt, J., Pei, S., Pryor, S., Shimizu, H., Isoda, H. 2010. Experimental Seismic Response of a Full-Scale Six-Story Light-Frame Wood Building. Journal of Structural Engineering 136(10): $1262-1272$. 